\title{
Hubungan Sanitasi Lingkungan dan Personal Hygiene Dengan Infeksi Soil Transmitted Helminths (STH) pada Anak Usia Sekolah Di Kecamatan Koto Tangah Kota Padang
}

Teguh Imana Nugraha ${ }^{1}$, Rima Semiarty ${ }^{2}$, Nuzulia Irawati ${ }^{3}$

\begin{abstract}
Abstrak
Sanitasi lingkungan dan personal hygiene yang buruk, merupakan dua faktor utama penyebab Infeksi Soil Transmitted Helminths. Pemerintah telah melakukan berbagai upaya pemberantasan, namun masih banyak masyarakat Indonesia yang menderita penyakit ini terutama di kalangan anak usia sekolah. Tujuan: Menentukan hubungan antara sanitasi lingkungan dan personal hygiene yaitu kebiasaan mencuci tangan, kebersihan kuku,dan penggunaan alas kaki terhadap infeksi Soil Transmitted Helminths (STH). Metode: Penelitian ini menggunakan desain analitik secara cross-sectional pada anak usia sekolah yang merupakan siswa TK Siaga dan SDN 48 Ganting kelas I di Kecamatan Koto Tangah sebanyak 61 orang yang dilaksanakan pada bulan Februari sampai Agustus 2018. Pengambilan sampel menggunakan teknik total sampling. Instrumen penelitian adalah kuesioner (pedoman wawancara) dan alat pemeriksaan laboratorium (parasitologi). Analisa data menggunakan metode Chi-square dengan derajat kepercayaan $(\mathrm{Cl})$ 95\%. Hasil: Angka infeksi STH sebesar 4.9\%, dengan rincian infeksi A.lumbricodes 4.9\%, infeksi T.trichiura 1.6\% dan infeksi cacing tambang $0 \%$. Uji statistik didapatkan nilai probabilitas untuk hubungan variabel sanitasi lingkungan, kebiasaan mencuci tangan, kebersihan kuku, dan penggunaan alas dengan infeksi STH masing - masing sebesar 0.551, 0.455, 0.226, dan 0.100. Simpulan: Tidak terdapat hubungan yang bermakna antara sanitasi lingkungan dan personal hygiene dengan infeksi STH pada anak usia sekolah di Kecamatan Koto Tangah Kota Padang.
\end{abstract}

Kata kunci: soil transmitted helminths, sanitasi lingkungan, personal hygiene

\begin{abstract}
Environmental sanitation and poor personal hygiene were the main factors of Soil Transmitted Helminths (STH) infections. The government has made various efforts to eradicates this diseases, but some Indonesian peoples were still suffered this infections, especially in schools-aged children's. Objectives: To determined the relation between environmental sanitation and personal hygiene, such as hand washing, nail cleanliness, and footwear's using habit's on STH infections. Methods: This was an analytic design method of cross-sectional study for school-aged children's in Koto Tangah which were the students of Siaga's kindergarten and the first grade students of forty eight elementary school from February until August in 2018. The samples of this study were sixty one schools-aged children's through total sampling technique. The data were obtains through laboratory tests, interviews, and observations using a questionnaires. Bivariate analysis was done by using Chi-square test with the confidence interval of $95 \%$ at the significance level of $5 \%(\alpha=0.05)$. Results: The rate of STH infection was $4.9 \%$. The infection rates of each Helminths types were Roundworms 4.9\%, Whipworms $1.6 \%$ and Hookworms $0 \%$. The statistical test indicates probabilities for the relation between the variable of environmental sanitation, hand washing, nail cleanliness, and footwear's using habits with STH infections were 0.551, 0.455, 0.226, and 0.100 respectively. Conclusions: No significant relation between environmental sanitation and personal hygienes on STH infections in school-aged children's in Koto Tangah, Padang.
\end{abstract}

Keywords: soil transmitted helminths infections, environmental sanitation, personal hygiene 
Affiliasi penulis : 1. Prodi Pendidikan Dokter Fakultas Kedokteran Universitas Andalas Padang (FK Unand), 2. Bagian IImu Kesehatan Masyarakat FK Unand, 3. Bagian Parasitologi FK Unand

Korespondensi: Teguh Imana Nugraha

Email:teguhimananugraha@gmail.com Telp: 082391535828

\section{PENDAHULUAN}

Peraturan Presiden Republik Indonesia Nomor 185 Tahun 2014 tentang Percepatan Penyediaan Air Minum dan Sanitasi (PPAMS), sanitasi merupakan suatu upaya yang dilakukan untuk menjamin terwujudnya kondisi yang memenuhi persyaratan kesehatan. Sanitasi meliputi pelayanan air limbah, persampahan, drainase, kesehatan, kebersihan, dan merupakan salah satu aspek pembangunan yang memiliki fungsi penting dalam menunjang tingkat kesejahteraan masyarakat. ${ }^{1}$

Berdasarkan data World Health Organization/ UNICEF's Joint Monitoring Programme for Water Supply and Sanitation tahun 2014, Indonesia menempati urutan ke-3 teratas sebagai negara dengan sanitasi yang buruk di dunia. Hal ini dikarenakan masih terdapat 109 juta penduduk Indonesia yang tidak mendapatkan akses sanitasi yang layak, serta masih banyaknya buang air besar sembarangan. Sanitasi lingkungan berkaitan dengan kesehatan, pola hidup, kondisi lingkungan permukiman, estetika, dan personal hygiene perorangan. $^{2}$

Personal hygiene atau higiene perorangan merupakan kebersihan diri sendiri yang dilakukan untuk mempertahankan kesehatan, baik secara fisik maupun psikologis. ${ }^{3}$ Penerapan sanitasi lingkungan dan personal hygiene yang buruk, serta didukung oleh keadaan iklim tropis di Indonesia yang memiliki kelembaban udara tinggi, akan menyebabkan Soil Transmitted Helminths (STH) yaitu penyakit kecacingan yang ditularkan melalui tanah berkembang dengan baik. ${ }^{4}$ Ada tiga jenis Soil Transmitted Helminths (STH) yaitu cacing gelang (Ascaris lumbricoides), cacing cambuk (Trichuris trichiura), dan cacing tambang (Ancylostoma duodenale dan Necator americanus). ${ }^{5}$

World Health Organization (WHO) pada tahun 2018 menyebut ada lebih dari 1,5 milyar orang atau sekitar $24 \%$ penduduk dunia terinfeksi STH, dimana angka kejadian terbesar berada di sub-Sahara Afrika,
Amerika, China dan Asia Timur. Lebih dari 267 juta anak usia pra-sekolah dan 568 juta anak usia sekolah bertempat tinggal di daerah yang beresiko dimana parasit ini mudah tertular dan membutuhkan pengobatan serta langkah pencegahan. ${ }^{6}$

Anak usia sekolah merupakan generasi penerus yang diharapkan bangsa dapat tumbuh, berkembang dan menjadi sumber daya manusia yang berkualitas di masa depan. Kecacingan menyebabkan anak akan mengalami gangguan konsentrasi belajar dan gangguan tumbuh kembang yang mempengaruhi kemampuan anak dalam menerima pelajaran sekolahnya. $^{7}$

Prevalensi penyakit kecacingan di Indonesia berdasarkan laporan survei Pengendalian dan Penyehatan Lingkungan (P2LP) tahun 2015 adalah sebesar 28,12\%. ${ }^{8}$ Padahal di tahun tersebut, pemerintah telah menetapkan target untuk menurunkan prevalensi penyakit kecacingan menjadi $<20 \%$. Ditinjau dari profil Dinas Kesehatan Kota Padang dari tahun 2012 sampai 2015, angka kejadian penyakit kecacingan yang dialami masih dalam taraf intensitas yang tinggi. Jumlah penderita kecacingan pada tahun 2012, 2013, 2014, dan 2015 adalah sebanyak 533, 1331, 1250, dan 776 kasus. Pada 11 kecamatan yang ada di Kota Padang, angka kejadian kecacingan tertinggi pada tiga tahun terakhir ini berada di Kecamatan Koto Tangah, yaitu sebanyak 690 kasus, 663 kasus, 341 kasus pada tahun 2013, 2014 dan 2015 dengan penderita terbanyak merupakan anak usia sekolah. ${ }^{9}$

Data penelitian yang telah dilaksanakan sebelumnya pada 60 siswa di SDN 31 Pasir Kandang, Koto Tangah, mendapatkan hasil siswa yang positif terinfeksi STH adalah sebanyak 31 orang (51.7\%). ${ }^{10}$ Penelitian lain yang dilakukan pada 81 siswa di SDN 27 Anak Air, Koto Tangah, sebanyak 13 orang (16.05\%) positif ditemukan telur Soil Transmitted Helminths (STH) pada potongan kuku jari tangan mereka. $^{11}$

Pengendalian penyakit kecacingan merupakan tindakan utama yang bertujuan untuk menurunkan prevalensi penyakit ini dalam rangka mewujudkan Indonesia sehat dan peningkatan mutu sumber daya manusia. Langkah utama untuk mengendalikan penyakit kecacingan adalah dengan memutuskan 
mata rantai lingkungan hidup cacing yang dapat dilakukan pada tingkatan cacing dalam tubuh manusia, lingkungan fisik, lingkungan sosial ekonomi dan budaya. ${ }^{12}$ Pemerintah telah melakukan berbagai upaya dalam pemberantasan penyakit ini, diantaranya melalui promosi kesehatan, surveilans kecacingan, pengendalian faktor resiko, penanganan penderita, dan pemberian obat pencegahan massal (POPM). Pada bulan Oktober 2017 lalu, pemerintah telah melakukan pemberian obat filariasis massal ke seluruh siswa sekolah dasar, dimana obat ini berefek dalam mematikan semua jenis cacing termasuk infeksi STH yang diperiksa. Pada kenyataannya masih banyak masyarakat Indonesia yang menderita penyakit ini. $^{13}$

Berdasarkan hal yang telah diuraikan di atas dan masih didapatkannya prevalensi kecacingan yang cukup tinggi dari hasil penelitian terdahulu, maka penulis tertarik untuk melakukan penelitian tentang "Hubungan sanitasi lingkungan dan personal hygiene dengan infeksi Soil Transmitted Helminths (STH) pada anak usia sekolah di Kecamatan Koto Tangah Kota Padang.

\section{METODE}

Jenis penelitian adalah studi analitik yang menggunakan rancangan cross sectional study yaitu penelitian yang dilakukan dengan sekali pengamatan pada suatu saat tertentu terhadap objek yang berubah, berkembang atau tumbuh menurut waktu. Metode yang digunakan adalah explanatory research yaitu mencari seberapa besar pengaruh faktor sanitasi lingkungan dan personal hygiene terhadap infeksi Soil Transmitted Helminths (STH) pada anak usia sekolah di Kecamatan Koto Tangah Kota Padang.

Penelitian dilakukan pada anak usia sekolah di Kecamatan Koto Tangah yang merupakan siswa TK Siaga dan SDN 48 Ganting kelas I yang dilaksanakan pada bulan Februari sampai Agustus 2018. Pemeriksaan telur Soil Transmitted Helmiths (STH) untuk menentukan status infeksi kecacingan dilakukan di Laboratorium Parasitologi Fakultas Kedokteran Universitas Andalas.
Populasi dalam penelitian ini adalah anak usia sekolah yang merupakan seluruh siswa-siswi TK Siaga dan SDN 48 Ganting kelas I, Kecamatan Koto Tangah. Sampel adalah bagian dari populasi sesuai dengan kriteria inklusi dan eksklusi. Kriteria Inklusi: siswa yang bersedia menjadi responden, siswa mengisi kuesioner, mendapat izin dari orang tua. Kriteria Eksklusi: meminum obat cacing dalam 2 bulan terakhir, tidak mengumpulkan kuesioner atau pot tinja melewati batas yang telah ditentukan (7 hari). Penelitian ini menggunakan total sampling dengan jumlah populasi anak usia sekolah siswa TK Siaga dan SDN 48 Ganting kelas I sebanyak 61 orang.

\section{HASIL}

\section{Karakteristik Responden}

Tabel 1. Distribusi karakteristik responden

\begin{tabular}{|c|c|c|c|}
\hline \multicolumn{4}{|c|}{ Responden } \\
\hline \multicolumn{4}{|c|}{ Jenis Kelamin } \\
\hline- & Laki laki & 28 & 45.9 \\
\hline- & Perempuan & 33 & 54.1 \\
\hline \multicolumn{4}{|c|}{ Tingkatan Kelas } \\
\hline- & TK & 20 & 32.8 \\
\hline- & SD & 41 & 67.2 \\
\hline \multicolumn{4}{|c|}{ Pekerjaan Orang Tua } \\
\hline- & Buruh & 27 & 44.3 \\
\hline- & Nelayan & 12 & 19.7 \\
\hline- & Pedagang & 13 & 21.3 \\
\hline \multirow{2}{*}{\multicolumn{4}{|c|}{$\begin{array}{l}\text { - } \quad \text { Pegawai } \\
\text { Swasta }\end{array}$}} \\
\hline & & & \\
\hline- & PNS & 3 & 4.9 \\
\hline
\end{tabular}

Tabel 1 menunjukkan bahwa sebanyak 28 orang (45.9\%) responden berjenis kelamin laki - laki dan sebanyak 33 orang $(54.1 \%)$ responden berjenis kelamin perempuan. Responden terdiri dari tingkatan TK sebanyak 20 orang (32.8\%) dan siswa kelas I SD sebanyak 41 orang (67.2\%). Prevalensi terbesar pekerjaan orang tua siswa berprofesi sebagai buruh yaitu sebanyak 27 orang (44.3\%), sedangkan jenis pekerjaan orang tua dengan prevalensi terkecil adalah pegawai negeri sipil (PNS) yaitu sebanyak 3 orang (4.9\%). 


\section{Sanitasi Lingkungan}

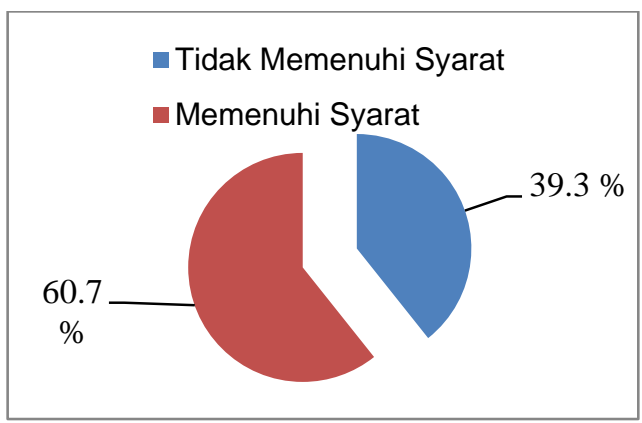

Gambar 1. Distribusi frekuensi sanitasi lingkungan rumah

Berdasarkan hasil observasi langsung ke rumah-rumah responden, diperoleh sanitasi lingkungan rumah yang memenuhi syarat adalah sebesar $60.7 \%$, dengan rincian yaitu sumber air yang berasal dari PDAM sebesar $63.9 \%$, ketersediaan tong sampah didalam rumah $91.8 \%$, dan kepemilikan jamban beserta SPAL sebesar $98.4 \%$.

\section{Personal Hygiene}

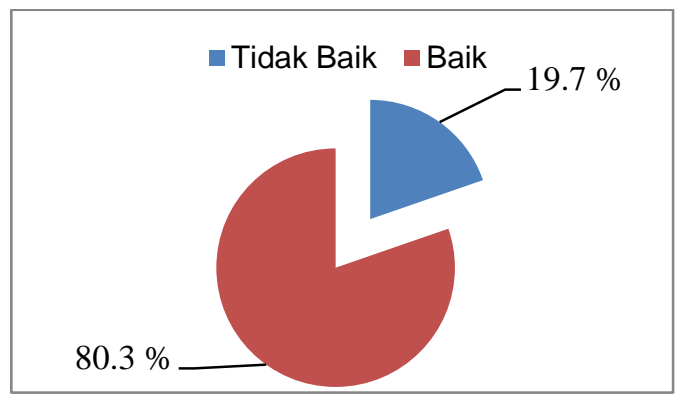

Gambar 2. Distribusi frekuensi kebiasaan mencuci tangan

Gambar 2 menunjukkan sebagian besar responden (80.3\%) memiliki kebiasaan mencuci tangan yang baik, dengan rincian mencuci tangan sebelum makan sebesar $88.5 \%$, mencuci tangan setelah bermain tanah $85.2 \%$, dan mencuci tangan menggunakan sabun setelah $\mathrm{BAB}$ adalah $82.0 \%$.

\section{Kebersihan Kuku}

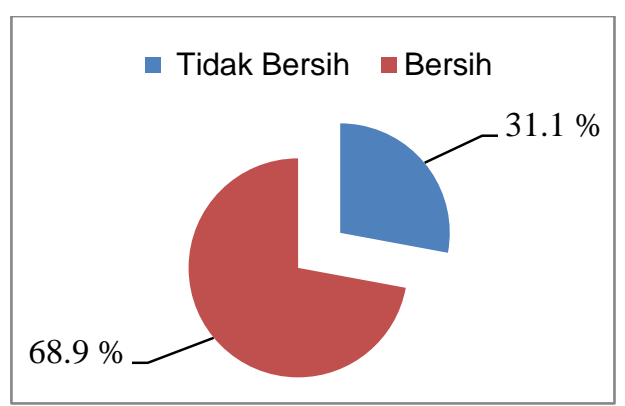

Gambar 3. Distribusi frekuensi kebersihan kuku

Gambar 3 menunjukkan sebagian besar responden (68.9\%) memiliki kebersihan kuku yang bersih, dengan rincian kuku anak yang bersih sebesar $63.9 \%$, kuku yang pendek $65.6 \%$, dan responden yang memotong kuku sekali dalam seminggu $82.0 \%$.

\section{Penggunaan Alas Kaki}

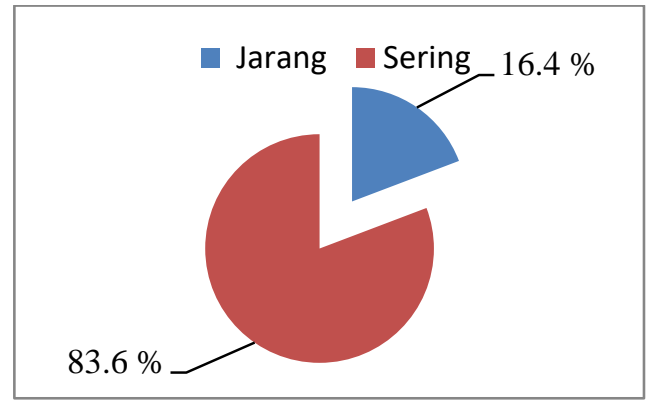

Gambar 4. Distribusi penggunaan alas kaki

Gambar 4 menunjukkan sebagian besar responden (83.6\%) memiliki kebiasaan sering menggunakan alas kaki, dengan rincian menggunakan alas kaki ketika keluar rumah sebesar $86.9 \%$, mencuci kaki setelah bermain sebesar $60.7 \%$, dan memakai alas kaki bila hendak BAB $67.2 \%$. 
Infeksi Soil Transmitted Helminths (STH)

$4,9 \%$

- Negatif $=$ Positif

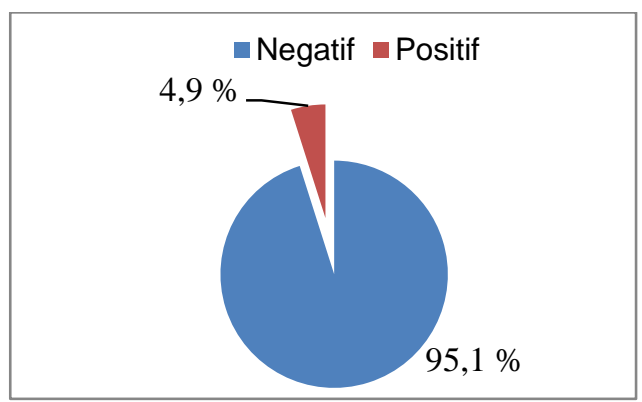

Gambar 5. Distribusi frekuensi infeksi soil transmitted helminths $(\mathrm{STH})$

Hasil pemeriksaan feses dengan menggunakan metode pemeriksaan langsung/sediaan basah larutan eosin $2 \%$ untuk mengetahui prevalensi infeksi STH pada responden menunjukkan hasil yang rendah. Pada Gambar 5 didapatkan sebanyak 3 orang dari 61 populasi $(4.9 \%)$ responden positif terinfeksi $\mathrm{STH}$. Jenis telur cacing yang ditemukan dalam pemeriksaan adalah telur Ascaris lumbricoides (cacing gelang), telur Trichuris trichiura (cacing cambuk), dan tidak ditemukan telur cacing tambang.

Tabel 2. Distribusi Infeksi Soil Transmitted Helminths (STH)

\begin{tabular}{llccc}
\hline \multirow{2}{*}{ Jenis Infeksi } & \multicolumn{4}{c}{ Frekuensi (F) } \\
\cline { 2 - 5 } & Positif & $\%$ & Negatif & $\%$ \\
\hline Ascaris & 3 & 4.9 & 58 & 95.1 \\
lumbricoides & 1 & 1.6 & 60 & 98.4 \\
Trichuris trichiura & 1 & 0 & 0 & 0 \\
Cacing Tambang & 0 & 0 &
\end{tabular}

Pada Tabel 2 didapatkan sebanyak 3 orang dari 61 populasi $(4.9 \%)$ angka yang positif terinfeksi STH. Jenis telur cacing yang ditemukan dalam pemeriksaan seperti telur Ascaris lumbricoides (cacing gelang), telur Trichuris trichiura (cacing cambuk), dan tidak ditemukan telur cacing tambang, sedangkan untuk distribusi infeksi STH berdasarkan jenis cacing (tabel 7) sebanyak 3 orang (5.3\%) merupakan persentase paling banyak yang positif terinfeksi A.lumbricoides, dan yang positif terinfeksi T.trichiura sebanyak dua orang $(1.5 \%)$, serta tidak ada yang terinfeksi cacing tambang $(0 \%)$. Pada 3 orang yang terinfeksi, terdapat 1 orang yang terinfeksi oleh kedua jenis cacing usus yaitu A.lumbricoides dan T.trichiura.

\section{Analisis Bivariat}

Tabel 3. Hubungan antara sanitasi lingkungan, kebiasaan mencuci tangan, kebersihan kuku, penggunaan alas kaki dengan infeksi soil transmitted helminths (STH)

\begin{tabular}{|c|c|c|c|c|c|}
\hline \multirow[t]{2}{*}{ Variabel } & \multicolumn{2}{|c|}{ Positif } & \multicolumn{2}{|c|}{ Negatif } & \multirow[b]{2}{*}{$\mathbf{p}$} \\
\hline & $f$ & $\%$ & $f$ & $\%$ & \\
\hline \multicolumn{6}{|c|}{ Sanitasi Lingkungan } \\
\hline Memenuhi & 1 & 1,6 & 37 & 60,7 & 0,551 \\
\hline \multicolumn{6}{|l|}{ Syarat } \\
\hline Tidak & 2 & 3,3 & 21 & 34,4 & \\
\hline \multicolumn{6}{|l|}{ Memenuhi } \\
\hline \multicolumn{6}{|l|}{ Syarat } \\
\hline \multicolumn{6}{|c|}{ Kebiasaan Mencuci Tangan } \\
\hline Baik & 2 & 3,3 & 48 & 78,7 & 0,455 \\
\hline Tidak Baik & 1 & 1,6 & 10 & 16,4 & \\
\hline \multicolumn{6}{|l|}{ Kebersihan Kuku } \\
\hline Bersih & 1 & 1,6 & 41 & 67,2 & 0,226 \\
\hline Tidak Bersih & 2 & 3,3 & 17 & 27,9 & \\
\hline \multicolumn{6}{|c|}{ Penggunaan Alas Kaki } \\
\hline Sering & 3 & 4,9 & 50 & 82,0 & 0,100 \\
\hline Jarang & 0 & 0 & 8 & 13,1 & \\
\hline
\end{tabular}

Berdasarkan analisis bivariat pada Tabel 3, menunjukkan bahwa tidak terdapat hubungan yang bermakna antara sanitasi lingkungan dan personal hygiene (kebiasaan mencuci tangan, kebersihan kuku, dan penggunaan alas kaki) dengan infeksi Soil Transmitted Helminths (STH).

\section{PEMBAHASAN}

Infeksi Soil Transmitted Helminths (STH) pada Anak Usia Sekolah di Kecamatan Koto Tangah Kota Padang

Penelitian yang dilakukan pada responden sebanyak 61 orang anak usia sekolah yang terdiri dari 20 orang siswa TK Siaga dan 41 orang siswa kelas I SDN 48 Ganting, melalui pemeriksaan feses di laboratorium dan didapatkan sebanyak 3 orang (4.9\%) positif yang terinfeksi cacing dengan rincian ditemukannya telur cacing Ascaris lumbricoides (cacing gelang) 3 orang (4.9\%), telur Trichuris trichiura (cacing cambuk) 1 orang (1.6\%) dan tidak ditemukan telur cacing tambang. 


\section{Hubungan antara Sanitasi Lingkungan dengan Infeksi Soil Transmitted Helminths (STH)}

Hasil uji Chi-square test hubungan sanitasi lingkungan rumah dengan infeksi kecacingan menunjukkan $p=0.551$ berarti tidak ada hubungan yang bermakna antara sanitasi lingkungan rumah dengan infeksi Soil Transmitted Helminths (STH). Dari 21 orang responden yang sanitasi lingkungan rumahnya tidak memenuhi syarat terdapat 2 orang (3.3\%) positif terinfeksi STH.

Keadaan ini menggambarkan bahwa kondisi sanitasi lingkungan rumah anak usia sekolah di Kecamatan Koto Tangah sudah memenuhi standar sebagai lingkungan yang memenuhi persyaratan kesehatan. Kondisi ini dipicu oleh multifaktor, diantaranya tingkat kemampuan ekonomi masyarakat, kurangnya pengetahuan tentang kondisi lingkungan yang baik, kurangnya kesadaran dalam pemeliharaan lingkungan dan kebijakan pemerintah yang kurang mendukung peningkatan kualitas kesehatan lingkungan ini. ${ }^{14}$

Hasil ini sesuai dengan penelitian di Kelurahan Purus Kota Padang dan di Kota Palu bahwa tidak ada hubungan yang bermakna antara sanitasi lingkungan rumah dengan infeksi STH. ${ }^{15,16}$ Berbeda dengan penelitian yang dilakukan di Kecamatan Teras Kabupaten Boyolali dan di Kecamatan Blang Mangat Kabupaten Lhoksumawe bahwa terdapat hubungan yang bermakna antara sanitasi lingkungan dengan infeksi STH. ${ }^{17,18}$

\section{Hubungan antara Personal Hygiene dengan Infeksi Soil Transmitted Helminths (STH)}

a. Hubungan antara Kebiasaan Mencuci Tangan dengan Infeksi Soil Transmitted Helminths (STH)

Hasil uji Chi-square test terhadap hubungan kebiasaan mencuci tangan dengan infeksi Soil Transmitted Helminths (STH) menunjukkan $p=0,455$, berarti tidak terdapat hubungan yang bermakna antara kebiasaan mencuci tangan dengan infeksi STH. Hasil penelitian pada 48 orang responden yang mempunyai kebiasaan mencuci tangan dengan baik terdapat 2 orang (3.3\%) positif terinfeksi STH.

Hal ini kemungkinan disebabkan karena sebagian besar responden sudah membiasakan mencuci tangan dengan sabun sebelum makan, setelah buang air besar dan setelah bermain dengan tanah. Kebiasaan tersebut sudah didapatkan para responden saat belajar dalam materi Usaha Kesehatan Sekolah (UKS) dalam pelajaran Olahraga dan Kesehatan, serta selalu diterapkan juga didalam lingkungan keluarga. Hasil pemeriksaan laboratorium ditemukan infeksi cacing A.lumbricoides lebih besar dibandingkan dengan jenis STH yang lain. Cacing A.lumbricoides ditularkan melalui mulut (oral) bukan menembus kulit melalui kaki sebagaimana cacing tambang dan Strongyloides stercoralis.

Hasil ini mendukung penelitian di Kecamatan Damau Kabupaten Kepulauan Talaud, Kelurahan Karangroto Semarang dan di Kabupaten Salatiga Yogyakarta bahwa tidak ada hubungan yang bermakna antara kebiasaan mencuci tangan dengan infeksi STH. ${ }^{19,20,21}$ Berbeda dengan penelitian yang dilakukan di Pulau Barrang Lompo Kota Talaud Makassar di Kota Lhokseumawe dan di Kecamatan Sibolga Kota bahwa ada hubungan yang bermakna antara kebiasaan mencuci tangan dengan infeksi STH pada siswa sekolah dasar. ${ }^{17,22,23}$

Perbedaan dari beberapa penelitian terdahulu, kemungkinan disebabkan dengan beberapa faktor higiene yang mempengaruhi infeksi STH. Dari penelitian menambahkan hubungan makanan jajanan dengan infeksi STH. Penelitian sebelumnya menemukan faktor lain yang mempengaruhi infeksi kecacingan selain pengaruh personal hygiene. Berbeda dengan studi yang peneliti lakukan tidak menambahkan tentang makanan jajanan siswa SD dalam pengaruhnya pada infeksi STH. ${ }^{17,23}$

b. Hubungan antara Kebersihan Kuku dengan Infeksi Soil Transmitted Helminths (STH)

Hasil uji Chi-square test hubungan kebersihan kuku dengan infeksi Soil Transmitted Helminths (STH) menunjukkan $\mathrm{p}=0.226$, berarti tidak ada hubungan yang bermakna antara kebersihan kuku dengan infeksi STH. Pada 41 responden yang mempunyai kebersihan kuku yang bersih terdapat 1 orang (1.6\%) yang positif terinfeksi STH. Sebagian besar responden memiliki kuku yang bersih (68.9\%), akan tetapi masih ditemukan responden yang memotong kuku satu kali dalam dua minggu atau lebih pada 11 orang (18.0\%), responden dengan kuku yang panjang sebanyak 21 
orang (34.4\%) dan responden yang mempunyai kuku kotor sebanyak 22 orang (36.1\%).

Penelitian ini sejalan dengan penelitian yang dilakukan di Kecamatan Damau Kabupaten Kepulauan Talaud, penelitian di Kelurahan Karangroto Semarang dan di Kabupaten Salatiga Yogyakarta bahwa tidak ada hubungan yang bermakna antara kebersihan kuku dengan infeksi STH. ${ }^{19,20,21}$ Studi ini berbeda dari penelitian yang dilakukan di Pulau Barrang Lompo Kota Makassar, di Kecamatan Sibolga Kota dan di Kota Lhokseumawe bahwa ada hubungan yang bermakna antara kebersihan kuku dengan infeksi STH. ${ }^{17,22,23}$

c. Hubungan antara Penggunaan Alas Kaki dengan Infeksi Soil Transmitted Helminths (STH)

Hasil Chi-Square test hubungan penggunaan alas kaki dengan infeksi Soil Transmitted Helminths (STH) menunjukkan $\mathrm{p}=0.100$, berarti tidak ada hubungan yang bermakna antara penggunaan alas kaki dengan infeksi STH. Pada 50 responden yang sering menggunakan alas kaki terdapat 3 orang (4.9\%) positif terinfeksi STH.

$\mathrm{Hal}$ ini kemungkinan disebabkan karena jenis infeksi yang sering ditemukan pada siswa di SD tersebut adalah A.lumbricodes. Pada 61 sampel yang diperiksa fesesnya, tidak ada yang terinfeksi cacing tambang. Perilaku anak yang sudah memakai alas kaki (sandal,sepatu) ketika bermain di atas tanah berpasir sering ditemukan. Hal ini mungkin sudah diajarkan oleh kedua orang tua dan guru untuk melindungi kaki dari bahaya benda asing dan penyakit kecacingan yang dapat membahayakan keselamatan mereka.

Sesuai dengan hasil penelitian yang dilakukan di Kecamatan Sibolga Kota, Kelurahan Karangroto Semarang, dan Kabupaten Kepulauan Talaud bahwa tidak ada hubungan yang bermakna antara penggunaan alas kaki dengan infeksi STH. 19,20,21. Hasil yang berbeda pada penelitian yang dilakukan di Kota Lhokseumawe dan di Kota Makassar bahwa ada hubungan yang bermakna antara penggunaan alas kaki dengan infeksi STH. Penelitian di Kecamatan Paseh Jawa Barat menunjukkan bahwa terdapat hubungan yang erat antara tanah yang tercemar telur A.lumbricodes dengan kejadian askariasis pada anak balita. ${ }^{24}$

Anak selalu menggunakan alas kaki, namun apabila bermain menggunakan media dan mainan tanah sementara mainan atau pola bermainnya selalu membuat tangan anak kontak dengan tanah, maka anak akan berpeluang terinfeksi cacing tambang. Kondisi inilah yang sangat memungkinkan menjadi penyebab perilaku menggunakan alas kaki tidak terbukti menjadi salah satu faktor risiko infeksi cacing tambang pada anak. ${ }^{25}$

\section{SIMPULAN}

Berdasarkan hasil penelitian dan setelah dilakukan serangkaian analisis serta pembahasan, maka disimpulkan bahwa tidak ada hubungan yang bermakna antara sanitasi lingkungan dan personal hygiene (kebiasaan mencuci tangan, kebersihan kuku, dan penggunaan alas kaki) dengan infeksi Soil Transmitted Helminths (STH) pada anak usia sekolah di Kecamatan Koto Tangah Kota Padang.

\section{UCAPAN TERIMA KASIH}

Terima kasih kepada semua pihak yang telah membantu dalam penelitian ini.

\section{DAFTAR PUSTAKA}

1. Sekretariat Kabinet RI. Peraturan Presiden Republik Indonesia Nomor 185 Tahun 2014 tentang percepatan penyediaan air minum dan sanitasi (PPAMS). Jakarta: Sekretariat Kabinet RI; 2014.hlm.3-4.

2. World Health Organization (WHO). WHO/ UNICEF's joint monitoring programme for water supply and sanitation. 2014. (diakses 20 Mei 2018). Tersedia dari: http://www.who.int/media centre/factsheets/fs366/en/

3. Alimul AH. Pengantar kebutuhan dasar manusia: aplikasi konsep dan proses dan keperawatan. Jakarta: Salemba Medika; 2006.hlm.2-3.

4. Zit Z. Pengobatan infeksi cacing yang ditularkan melalui tanah dengan kombinasi mebendazol dan pirantel pada anak. Majalah Kedokteran Sriwijaya. 2000;32(1):46-50. 
5. Departemen Kesehatan RI (Depkes RI). Pedoman umum program nasional pemberantasan cacingan di era desentralisasi. Jakarta: Depkes RI; 2006.hlm.4.

6. WHO. Soil transmitted helminths infections. 2018 . (diakses 24 Mei 2018). Tersedia dari: http:// www.who.int/en/news-room/factsheets/detail/ soil transmitted-helminth-infections

7. Supali T, Margono SS, Abidin SA. Buku ajar parasitologi kedokteran. Edisi ke-4. Jakarta: FKUI; 2009.hIm.16-8.

8. Direktorat Jenderal Pengendalian dan Penyehatan Lingkungan. Profil pengendalian dan penyehatan lingkungan. Jakarta: Direktur Jenderal Pengendalian-Penyehatan Lingkungan; 2015 (diunduh 24 Mei 2018). Tersedia dari: http:// www. depkes.go.id/article/view/15110900005/direktoratjenderalpengendalian-penyakit-dan-penyehatanlingkungan.html

9. Dinas Kesehatan Kota Padang (Dinkes Kota Padang). Laporan bulanan 1 (LB. 1) data kesehatan tahunan. Padang: Dinkes Kota Padang; 2018 (diunduh 03 Januari 2018). Tersedia dari: http:// ppid.padang.go.id/home/downloadfile/4\% 20Renstra\%20DKK\%202012-2015.pdf

10. Azika WN. Hubungan infeksi soil transmitted helminth dengan status gizi pada siswa SDN 31 Pasir Kandang Kota Padang [skripsi]. Padang: Universitas Andalas; 2017.

11. Agustina C. Hubungan antara personal hygiene dengan gambaran telur soil transmitted helminths pada kuku jari tangan siswa SDN 27 Anak Air, Koto Tangah, Padang [skripsi]. Padang: Universitas Andalas;2016.

12. Sutanto. Pengaruh infeksi kecacingan dengan status gizi anak [tesis]. Yogyakarta: Universitas Gadjah Mada;1992.

13. Kementerian Kesehatan RI (Kemenkes RI). Peraturan menteri kesehatan Republik Indonesia nomor 15 tahun 2017 tentang penanggulangan cacingan. Jakarta: Kemenkes Rl; 2017 (diunduh 20 Mei 2018). Tersedia dari: http://ditjenpp.Kemen kumham.go.id/arsip/bn/2017/bn438-2017.pdf
14. Anies. Penyakit akibat kerja. Jakarta: Alex Media Komputindo; 2005.hlm.55-7.

15. Kusmi H. Hubungan sanitasi lingkungan rumah dengan kejadian askariasis dan trikuriasis pada siswa SDN 29 Purus, Padang ([kripsi]. Padang: Universitas Andalas; 2015.

16. Chadijah S. Hubungan pengetahuan, perilaku, dan sanitasi lingkungan dengan angka kecacingan pada anak sekolah dasar di kota palu. Tersedia dari:http://ejournal.litbang.kemkes.go.id/index.Php/ $\underline{\mathrm{mpk} / \text { article/ view/ } 3487}$

17. Jalaluddin. Pengaruh sanitasi lingkungan, personal hygiene dan karakteristik anak terhadap infeksi kecacingan pada murid sekolah dasar di Kecamatan Blang Mangat Kota Lhokseumawe [tesis]. Medan: Universitas Sumatera Utara; 2009.

18. Mahmudah U. Hubungan sanitasi lingkungan rumah terhadap kejadian infeksi kecacingan pada anak sekolah dasar [skripsi].Yogyakarta: Program Studi S1-IImu Gizi Universitas Respati Yogyakarta; 2017.

19. Nusa LA. Hubungan antara higiene perorangan dengan infestasi cacing usus pada siswa SD yayasan pendidikan Imanuel Akas Kec. Damau Kab. Kepulauan Talaud [tesis]. Manado: Program Studi Fakultas Kesehatan Masyarakat Universitas Sam Ratulangi; 2013.

20. Endriani. Beberapa faktor yang berhubungan dengan kejadian kecacingan pada anak usia 1-4 tahun [tesis]. Semarang. Fakultas Kesehatan Masyarakat Universitas Muhammadiyah Semarang; 2010.

21. Sofiana L. Hubungan perilaku dengan infeksi soil transmitted helminths pada anak SD MI Asas Islam, Kalibening, Salatiga [tesis]. Yogyakarta; Fakultas Kesehatan Masyarakat Universitas Ahmad Dahlan; 2010.

22. Pertiwi AC. Analisis faktor praktik hygiene perorangan terhadap kejadian kecacingan pada murid sekolah dasar di Pulau Barrang Lompo Kota Makassar [tesis]. Makassar: Fakultas Kesehatan Masyarakat UNHAS; 2013. 
23. Rahmad RZ. Hubungan higiene perorangan siswa dengan infeksi kecacingan anak SD Negeri di Kecamatan Sibolga Kota Sibolga [tesis]. Medan: Pasca Sarjana Universitas Sumatera Utara; 2008.

24. Agustina. Telur cacing Ascaris lumbricoides pada tinja dan kuku anak balita serta pada tanah di
Kecamatan Paseh Kabupaten Bandung, Jawa

Barat [skripsi]. Medan: Fakultas Kesehatan Masyarakat Universitas Sumatera Utara; 2000.

25. Sumanto D. Faktor resiko infeksi cacing tambang pada anak sekolah [tesis]. Semarang: Universitas Diponegoro; 2010. 